\title{
Becoming everything - scattered actualizations with curious bodies- darkness-forest assemblage
}

craving for what might become

when thinking there is no secrets to be revealed by science (Barad, 2008)

in relation to what, you say?

don't know, "might", I said

don't know what "might", might be

it is not yet

it is however political

always

it is methodologies bearly sniffed with that craves (us?)

and philosophy

a monist one and others

crave for a language that 'do something towards transforming

particular ways of knowing and̈ producing knowledge' (Dillard, 2000,

p. 662)

'a minor language'

several minor languages

characterized by 'sobriety', by 'variation'

that is 'a becoming-minor of the major language'

'achieved by streching tensors' trough our own language (Deleuze \& Guattari, 1987, p. 116)

streching language with curious bodies, darkness and forest collective experimenting, collective trying out collectively seeking less painful research practices and ways of being (Greenhough \& Roe, 2010)

in-between major-scientific-language and becoming-minor-language 
turning away from light

the oh so bright light

away from the majesty of light

light as a force appreciated in philosophy, science and art

(Macauley, 2009)

turning our backs on becoming enlightened, perhâps

away from constanst

away from the 'the average adult-white-heterosexual-European-

male-speaking a standard language' assuming power and

domination (Deleuze \& Guattari, 1987, p. 116)

did we we touch upon some of the same issues raised in an 'endarkened epistemology' (Dillard, 2000)?

did we work against the metaphors of research?

away from research as reciepe and towards research as a

responsibility (Dillard, 2000)?

perhaps towards doing response-ability (Haraway, 2012)?

not overlook darkness

not undervalue darkness

not aproach darkness as malign (Macauley, 2009)

instead

morphing with darkness

cultivating our sensitivity towards the environment (Greenhough $\&$ Roe, 2010)

becoming creatures of darkness and forest

'becoming-minor' (Deleuze \& Guattari, 1987)

become 'far-seers' with our ambiguities (Deleuze \& Guattari, 1987,

p. 222)

being in the in-betweenness

of major-scientific-language and becoming-minor-language as politics 
might be that of hinging on to the production of differences love duration through 'philosophical intuition' (Grosz, 2005) strive to become pregnant with other realities

Barad, K. (2008). Living in a posthuman material world: Lessons from Schrödingers cat. In A. Smelik \& N. Lykke (Eds.), Bits of life: Feminism at the intersections of media, bioscience, and technology (pp. 165-176). Seattle: University of Washington Press.

Deleuze, G., \& Guattari, F. (1987). A thousand plateaus: Capitalism and schizophrenia (B. Massumi, Trans. 2004 ed.). London: Continuum (Originally published as Milles Plateaux, volume 2 Capitalisme et Schizophénie, 1980).

Dillard, C. (2000). The substance of things hoped for, the evidence of things not seen: Examining an endarkened feminist epistemology in educational research and leadership. Qualitative Studies in Education, 13(6), 661-681.

Greenhough, B., \& Roe, E. (2010). From ethical principles to response-able practice. Environment and Planning D: Society and Space, 28, 43-45.

Grosz, E. (2005). Bergson, Deleuze and the becoming of unbecoming. parallax, 11(2), 4-13.

Haraway, D. (2012). Awash in urine: DES and premarin(r) in multispieces response-ability. Women's Studies Quarterly, 40(1 \& 2), 301-316

Macauley, D. (2009). Night and shadows. Environment, Space, Place, 1(2), 51-76. 